\title{
Development and acceptability of mead wine with calamansi fruit flavor
}

\author{
Mary Ann I Baua \\ Isabela State University, San Mariano, Isabela 3332, Philippines \\ *Email:maryann.i.baua@isu.edu.ph
}

\section{ARTICLE HISTORY}

Received: 25 December 2020

Accepted: 22 May 2021

Available online: 01 July 2021

\section{KEYWORDS}

Income

Commodity

Appearance

Texture

Aroma

Enterprise

\begin{abstract}
The study discusses the development and acceptability of Mead wine with Calamansi fruit flavor. Mead can have a wide range of flavors depending on the source of the honey, added substances counting natural product and flavors, the yeast utilized amid maturation and the maturing method. In this study, the researcher used calamansi fruit as its flavour since there is a rich cultivation and plantation of calamansi fruit in the locale of the study. Thirty individuals assessed the mead wine with calamansi fruit flavour in terms of appearance, aroma, flavour and texture. The research has used various statistical treatments such as Mean and T-test in evaluating the obtained data. It was found out that the mean wine with calamansi fruit flavor had an alcohol content of $12 \%$. Furthermore, the respondents extremely like the mead wine with calamansi flavour because of its appearance and aroma which obtained the highest appraisal of the respondents based on their sensory evaluation. The study uncovered that calamansi fruit flavour has the potential to be utilized as an ingredient for mead wine production. Moreover, amid the appraisal of the respondents, the aroma, flavour, appearance and texture of the produced mead wine with calamansi fruit flavour was essentially influenced. Generally, the taster respondents have extremely liked the mead wine with calamansi fruit flavour. Therefore, it is a highly appropriate commodity in the community and can be a potential income source and generating enterprise.
\end{abstract}

\section{Introduction}

Wine is considered as one of the most popular alcoholic beverages in the world. Traditionally, it is made with grape juice. However, there are numerous studies on wine-making using different fruits such as banana, mango, strawberry, jam, litchi, orange, calamansi and guava. Besides fruit, other materials are also a good source of wine, such as tea leaves, rice and nipa. In Philippines, the most common types of wine produced are from tropical fruits, rice and sugarcane (1).

Mead is probably the oldest fermented drink in the world but commercially difficult to find (2). The technical term mead is used in the case of honey wine produced by fermentation of diluted honey. Various additives, such as fruit pulps or juices, citric acid etc., may be added before or after fermentation of the fruit used for making the said wine.

In prehistoric times, honey was the only concentrated sweet substance (3). Honey was modified and known as the primary alcoholic drink to Indians thousands of years ago (4).
The honey fermentation is used in various types like mead, sherry, vino and sweet wines and has different flavours according to the floral source of sweetness, additives and yeast. Honey, which is the main ingredient in mead making, displays many colour and composition variations that are likely to influence the best production of mead. Honey has several major ingredients, which are responsible for the mead's antioxidant function, as one of its special characteristics (5).

One of the major ingredients of mead wine is Calamansi. calamansi (Citrus microcarpa), moreover known as calamondin, Philippine lime or Philippine lemon, is an economically vital citrus hybrid overwhelmingly developed within Philippines, and it is one of the main cultivars in the Philippines that are native to the country as a taste in the preparation of mead wine. Furthermore, it is also considered as one of the smallest and least expensive fruits in the market. From its pulp, distilled juice can be made into wine. It typically takes 3-4 weeks for fermentation. With its citrus flavour, calamansi has a unique taste. It is a small fruit, but it has many advantages to offer for 
one's body. This fruit helps boost beauty, promotes the immune system and leads to loss of weight (6).

In addition, Calamansi also contributes to strengthening the body system (7). It is a watersoluble vitamin that helps healthy bones and teeth. It helps to boost the ability of the body to heal injuries. The calamansi juice is a liver purifier which aids in the purification of liver (8). It helps to reduce the weight loss of toxins in our body. It decreases the feeling of burning. It helps improve the suddenness to minimise the inconvenience of coldness flu and fever. High pressure can be regulated. Calamansiwater combination can help a person with breathing problems (9). Moreover, it was found out that calamansi has anti-ageing properties that are essential for keeping the skin tight and firm (10).

Producing mead wine with calamansi flavour requires careful selection of the ingredients to be used, the fermentation process to be applied, and the proportion of the ingredients in developing and producing a mead or honey wine. The goal of this research project was to produce high-quality mead or honey wines infused with calamansi fruit flavour. It also aimed to determine the alcohol content of mead wine with calamansi fruit flavor as well as its acceptability to its respondents. A sensory assessment was utilised to determine the acceptability of the product among taster respondents focusing on its appearance, aroma, flavour and texture. In the end, the study also evaluated the return of investment considering that it can be a potential income source and generating enterprise.

\section{Materials and Methods}

The ingredients used in making the mead wine with calamansi fruit flavour were $600 \mathrm{ml}$ of honey, $600 \mathrm{ml}$ of calamansi fruit juice, $35 \mathrm{gm}$ of yeast and $2000 \mathrm{ml}$ of water. The tools and equipment used were a jar, measuring cup, bowl, bottle, casserole, cheese cloth, string and LPG gas.

The procedure involved in making the mead wine with calamansi fruit flavour were the following: (a) Sterilise all the materials needed, (b) measure all the ingredients, (c) slice and extract the calamansi fruit, (d) boil $2000 \mathrm{ml}$ of water and dilute the honey, stir it carefully. Let it cool, (e) activate the $35 \mathrm{gm}$ of yeasts in a $1 / 2$ cup of lukewarm water then combine it to the mixture of $2000 \mathrm{ml}$ of water and honey, (f) add the calamansi fruit juice to the treatment together with the activated yeast, (g) pour the wine in a jar, then cover it with air-lock, (h) ferment the mixture for three to one year and (i) put it in a sterilised bottle.

To determine the alcohol content of the mead wine with calamansi fruit flavour, the equipment used were distillation apparatus, alcohol hydrometer, measuring cylinder, thermometer, retort stands and clamps. The study took two readings with what was known as a wine hydrometer: one reading was taken before the fermentation started and the other reading was taken after the fermentation had finished.

\section{Research Design}

An experimental approach was used in this analysis (21). The mead wine with calamansi fruit flavour was determined by its development and acceptability by evaluating the alcohol content and sensory assessment as to its appearance, aroma, taste, texture and general acceptability. The affective and analytical test evaluations were employed in this research.

\section{Sensory Evaluation of Mead wine with Calamansi fruit flavour}

The physical properties of calamansi fruit-flavoured mead wine, such as appearance, aroma, flavour and texture, have been determined by organoleptic testing or assessment of the consumer's acceptability of wine. To determine the final product's market acceptability, 30 young male and female individuals, comprising of 15 drinkers and 15 non-drinkers, who appeared to be physically fit, were selected as taste panellists using a purposeful sampling to assess the manufactured mead wine using a 4-point Likert Scale Quality Score. Taste panellists were asked to rate the wine sample using the scoring sheet which was clearly explained and discussed to them. The wine was processed accordingly and was served in a clean, clear wine glass.

The Likert scale below was used in the evaluation:

\begin{tabular}{ll}
\hline \multicolumn{1}{c}{ Scale } & \multicolumn{1}{c}{ Description } \\
\hline $3.26-4.0$ & Extremely Like \\
$2.51-3.25$ & Like \\
$1.76-2.5$ & Dislike \\
$1.0-1.75$ & Extremely Dislike \\
\hline
\end{tabular}

In terms of statistical treatment used in the study, the data were analysed using weighted mean to attain the summary rating and describe the sensory evaluations of the wine as well as T-test to determine the existence of significant differences between the two samples of produced mead wine.

\section{Results and Discussion}

The following presents the results and discussion of the study in the following order: alcohol content of mead wine with calamansi fruit flavor; sensory evaluation of mead wine with calamansi fruit flavor using the four parameters; appearance, aroma, flavor and texture; the test of significant difference of the product and; the return on investment.

\section{Alcohol Content of MeadWine with Calamansi Fruit Flavor}

Using the wine hydrometer test, the wine hydrometer was taken at the same time the yeast was added to the wine. During this point in the wine making process, the wine reading test was around $13 \%$. The reading was at the point where the surface of the liquid crosses the scale. This reading indicated how much alcohol the wine can have if all the sugars were fermented. The number or figure obtained from the gravity hydrometer down were saved or recorded.

Another reading was taken with the hydrometer after the fermentation had completed. The reading 
obtained was around +1 on the Potential Alcohol scale. By comparing the two gravity hydrometer readings, the study determined the wine's alcohol level or content which was equivalent to $12 \%$.

By comparing the hydrometer readings, the study determined with great accuracy how much alcohol content was in the mead wine with calamansi fruit flavor. Moreover, the reading was accurately determined after the observation based on how high or low the hydrometer had floated in a liquid. The study tried to figure out how much sugar was in the wine or wine must have. It was found out that the higher the wine hydrometer floats, the more sugar there was in the liquid and the opposite held true as well.

\section{Sensory Evaluation of the Respondents}

Table 1 showes the mutual assessment of the respondents on determining the acceptability of the product focusing on its appearance, aroma, flavor and texture, with an average mean of 3.92 specifying that the mead wine with calamansi fruit flavour was highly accepted by the respondents.

Based on the given indicators, "appearance" and "aroma" obtained the highest weighted mean equivalent to 3.96 with an interpretation of "Extremely Like". It was followed by "flavor" with a weighed mean of 3.93 and a verbal interpretation of "Extremely Like".

of the four indicators listed,"texture" got the lowest weighted mean of 3.83 with a verbal interpretation of "Extremely Like”.

Table 1. Sensory evaluation of the respondents

\begin{tabular}{lcl}
\hline Variables & Weighted mean & $\begin{array}{c}\text { Descriptive } \\
\text { Interpretation }\end{array}$ \\
\hline Appearance & 3.96 & Extremely Like \\
\hline Aroma & 3.96 & Extremely Like \\
\hline Flavor & 3.93 & Extremely Like \\
\hline Texture & 3.83 & Extremely Like \\
\hline Overall & 3.92 & Extremely Like \\
\hline
\end{tabular}

The foregoing findings and implications lend support to the earlier reports (12) as he explained that as the wine has been poured within the glass, the time to start its evaluation has finally come. The examination of wine could be a handle made of distinctive and particular stages and the primary one is approximately its appearance. Wine's appearance assessment is, maybe, the assessment stage that takes little time in case compared to others, and it likely is the stage where one pays the slightest consideration, this can be likely since it is considered as an examination having small significance. Besides, wine's appearance assessment can moreover appear a few and conceivable surrenders and flaws as well as deciding their causes, final but not the slightest, it can tell around wine's age, indeed in spite of the fact that in a very inexact way, as well as around the generally state and advancement.

As the assessment of the appearance is the primary investigation conducted on wine tasting, that's the stage that permits us to "make friends" with wine, it is fundamental to pay the right attention to this in order to get ready the tester to have the correct inclination and concentration for the taking after stages (13). It ought to moreover be taken note that wine's appearance, that's the result of this assessment, can contrarily or emphatically impact the taster's inclination towards the wine itself: a wine which is considered to have a awful appearance, or besides not having those characteristics that would meet taster's desires, adversely incline the tester to all the others stages, in a sense, this is often what happens when one sees something tastefully wonderful and as a result of this mental satisfaction, it'll be emphatically impacted and inclined (14). In any case, a proficient tester must not be impacted by what he or she sees, at least not totally, he or she must consider the appearance assessment as a fundamental stage in order to specific an objective and honest reaction.

Smelling the wine, or "nosing" it as a few wine lovers say, is a vital portion of the wine tasting custom (15). Aromas can inspire solid recollections and affiliations, so the scent of a wine might make it more engaging to drink, in a perfect world bringing to intellect another thing the person like to smell.

Wines with citrus fruits flavours are wellaccepted by consumers all over the world because of their attractive colors, pleasant flavors and aroma, as well as for their well-known nutrition and healthpromoting values (16). Citrus fruits are a good source of dietary antioxidants, which are vital in both health promotion and in the prevention and treatment of various human chronic and degenerative diseases.

Table 2 shows the test of significant difference in the sensory evaluation of the two samples of mead wine with calamansi fruit flavor in terms of appearance, aroma, flavor and texture. It reveals that the computed t-values of 3.98 (appearance), 4.22 (aroma), 4.25 (flavor), 5.71 (texture) are more significant than the critical value of 2.04, which suggests that the second sample is significantly more preferred than the first sample with respect to the said criteria.

Learning how to taste wine includes locks in the senses of sight, smell, taste and touch, all with the objective of finding a wine to suit your sense of taste (16). Wine has been a part of human civilization for thousands of years, but it didn't continuously taste as great as what we drink nowadays (17). Wine quality has made strides exponentially over the past century as wine makers find way better methods for wine developing and wine making. Worldwide commerce permits us to drink wines from all corners of the world, and the web permits each consumer to share their supposition, which makes it all the more vital to

Table 2. Test of Significance on the Meadwine with Calamansi fruit flavor

\begin{tabular}{lcccl}
\hline Variables & $\begin{array}{c}\text { Computed } \\
\text { t-value }\end{array}$ & $\begin{array}{c}\text { Critical } \\
\text { Value }\end{array}$ & Decision & Interpretation \\
\hline Appearance & 3.98 & 2.04 & Reject & Significant \\
\hline Aroma & 4.22 & 2.04 & Reject & Significant \\
\hline Flavour & 4.25 & 2.04 & Reject & Significant \\
\hline Texture & 5.71 & 2.04 & Reject & Significant \\
\hline
\end{tabular}


know how to taste wine so you'll get to know what's in your glass and discover wines you genuinely appreciate (18).

\section{Return of Investment}

\section{A. Input}

$600 \mathrm{ml}$ honey

300.00

$600 \mathrm{ml}$ calamansi fruit

60.00

35 gm yeast

10.00

$2000 \mathrm{ml}$ water

10.00

4 bottles with seal and cup

152.00

LPG

20.00

Total

$612.00 \mathrm{php}$

\section{B. Output}

4 Bottles of meadwine with calamansi flavor

4 Bottles@250 php/bottle =

\section{Net income (B-A)}

$1,000.00$ php

388.00

\section{Return on investment}

(Net income/gross expenses)

Investing in wine could be a beneficial elective venture choice for financial specialists and wine consumers to broaden their portfolio (19). The mead wine showcase has outperformed most worldwide values and exchange-traded stores (20). Mead wine encompasses a track record of conveying steady development and solid returns that has outperformed budgetary markets and commodities over the long term. Investing in mead wine is both pleasant and exceptionally fulfilling, giving the opportunity to investigate, get it and claim a few of the finest extravagance items within the world. Mead wine's chronicled execution has driven numerous speculators to see it as a substantial, elective resource that can be utilized to differentiate a speculation portfolio, conveying steadiness and development that can de-risk a venture methodology and secure wealth.

Mead wines wines which are seen as investment-grade are of an amazingly high quality, perceived by the world's driving critics, delivered beneath strict conditions by the most excellent wine makers and, imperatively, the request for these wines supports a dynamic auxiliary advertisement which drives costs to exceptionally critical levels. Esteem is improved with irregularity and great provenance, by this we mean a review path of proprietorship which ensures the wine has been put away in idealized conditions to preserve the great quality of the wine.

\section{Conclusion}

The study aimed to develop and find out the acceptability of mead wine with calamansi fruit flavor. Specifically, the study aimed to: develop mead wine with calamansi fruit flavor, identify the alcohol content in mead wine with calamansi fruit flavor; determine the acceptability of mead wine considering its appearance, aroma, flavor and texture and evaluate the return on investment of the produced mead wine with calamansi flavor. The study revealed that calamansi fruit flavor has the potential to be used as an ingredient for mead wine production. Likewise, during the assessment of the respondents, the aroma, taste, presentation and texture of the produced mead wine with calamansi fruit flavor was significantly affected. Results revealed that mead wine with calamansi fruit flavor was most accepted or extremely liked by the taster respondents. Mead wine with calamansi fruit flavor will have a positive return on investment in the commercialisation of the product in the market.

\section{Recommendation}

In order to boost the development and market acceptability of the mead wine with calamansi fruit flavor, the packaging of the product should be enhanced. The expiration date should be included in the packaging. Product innovations should be sustained. Further studies on the utilisation of other fruits as flavouring to wine should be considered. Lastly, further studies on the fermentation process of mead wine with calamansi flavour should be given emphasis.

\section{Acknowledgements}

The author would like to acknowledge the financial help from Isabela State University- San Mariano Campus, San Mariano, Isabela.

\section{Conflict of interests}

The author has no conflict of interest.

\section{References}

1. Willaert RG. Improvement of malvar wine quality by use of locally-selected Saccharomyces cerevisiae Strains. fermentation 2, 1-13. MDPI Publisher, USA. 2016. https://doi.org/10.3390/fermentation2010007

2. Douglas P, Meneses FJ, Jiranek V. Comparative fermentation behaviour. National Library of Medicine, 8600 Rockville Pike Bethesda, MD 20894. 2019. https://doi.org/10.1111/j.13652672.2005.02755.x

3. Cortes GH, 1, Lopez JA, Lopez EH, Marroquin GA, Rodriguez JV Montaño DD. Effect of pH, aeration and feeding non-sterilized agave juice in a continuous agave juice fermentation. National Library of Medicine 8600 Rockville Pike Bethesda, MD 20894. 2019. https://doi.org/10.1002/jsfa.3957

4. Pinheiro AD, Rocha MV, Macedo, GR, Goncalves LR. Evaluation of cashew apple juice for the production of fuel ethanol National Library of Medicine 8600 Rockville Pike Bethesda, MD 20894. 2019. https://doi.org/10.1007/s12010-007-8118-7

5. Gupta R, Sharma KK, Kuhad RC. Separate hydrolysis and fermentation (SHF) of Prosopis juliflora, a woody substrate, for the production of cellulosic ethanol by Saccharomyces cerevisiae and Pichia stipitis-NCIM 3498. National Library of Medicine 8600 Rockville Pike Bethesda, MD 20894. 2019. https://doi.org/ 10.1016/j.biortech.2008.08.033

6. Agbogbo FK, Coward-Kelly G. Cellulosic ethanol production using the naturally occurring xylose-fermenting yeast, Pichia stipitis. National Library of Medicine 8600 Rockville Pike Bethesda, MD 20894. 2019. https://doi.org/10.1007/s10529-0089728-z

7. Matsushika A, Inoue $\mathrm{H}$, Kodaki $\mathrm{T}$, Sawayama S. Ethanol production from xylose in engineered Saccharomyces cerevisiae strains: current state and perspectives. National 
Library of Medicine 8600 Rockville Pike Bethesda, MD 20894. 2019. https://doi.org/10.1007/s00253-009-2101-x

8. Pacheco AM, Gondim DR, Gonçalves LR. Ethanol production by fermentation using immobilized cells of Saccharomyces cerevisiae in cashew apple bagasse. National Library of Medicine 8600 Rockville Pike Bethesda, MD 20894. 2019. https://doi.org/ 10.1007/s12010-009-8781-y

9. Najafpour G, Younesi $\mathrm{H}$, Syahidah $\mathrm{Ku}$ Ismail K. Ethanol fermentation in an immobilized cell reactor using Saccharomyces cerevisiae. National Library of Medicine 8600 Rockville Pike Bethesda, MD 20894. 2019. https://doi.org/ 10.1016/j.biortech.2003.09.009

10. Vidrih R, Hribar J. Studies on the sensory properties of mead and also the formation of aroma compounds associated with the sort of honey. Acta Aliment. 2007;36:151-62. USDA pubAg. 2007. https://doi.org/10.1556/AAlim.36.2007.2.2

11. Pascoal, A.,Oliveira, J.M., Pereira, A.P., Féas, X., Anjos, O., Estevinho, L.M. Influence of fining agents on the sensorial characteristics and volatile composition of mead. J Inst Brew. 2017;123:562-71. Wiley Online Library. https://doi.org/10.1002/ jib.445

12. Piljac-žegarac J, Martinez S, Valek L, Stipčević T,; KovačevićGanić K. Correlation between the phenolic content and DPPH radical scavenging activity of selected Croatian wines. Acta Alimentaria. 2007;36(2):185-93. USDA pubAg. https://doi.org/ 10.1556/AAlim.2007.0005

13. Slačanac V, Hardi J, Pavlović H, Čuržik D, Lučan M. Inhibition of growth of Staphylococcus aureus by goat's and cow's milk fermented with Bifidobacterium longum. Acta Alimentaria. 2007;36(2):163-72. USDA pubAg. 2007. https://doi.org/ 10.1556/AAlim.36.2007.2.2

14. Amerine MA, Kunkee RE. Microbiology of wine making. Ann Rev Microbiol. 2002;2:232-58. Annual Reviews Publication. USA. https://doi.org/10.1146/annurev.mi.22.100168.001543

15. Facundo HV, Garruti DD, Carlos DS, Beatriz RC, Franco ML. Influence of various banana cultivars on volatile compounds during ripening in cold storage. Food Research International Journal. 2012

49:626-33. https://doi.org/10.1016/j.foodres.2012.08.013

16. Gaglio R, Alfonzo A, Francesca N, Corona O, Di Gerlando R, Columba P, ,Moschetti G. Production of the Sicilian distillate "Spiritu re fascitrari" from honey by-products: a stimulating source of yeast diversity. Int J Food Microbiol. 2017;261:62-72.
ResearchGate

Publishing.

USA.

https://doi.org/10.1016/j.ijfoodmicro.2010.09.016

17. Jussier D, De Orduña RM, Morneau AD. Effect of simultaneous inoculation with yeast and bacteria on fermentation kinetics and key wine parameters of cool climate chardonnay. Applied Environmental Microbiology. 2006;72(1):221-27. American Society of Microbiology. USA. https://doi.org/ 10.1128/AEM.72.1.221-227.2006

18. Kunkee RF, Amerine MA. Yeast in Wine Making. In: Rose, H.A and Harrison, J.S. (Edn). The Yeast. Academic Press, London. 2002;5- 71. https://doi.org/10.5897/IJBMBR11.034

19. Fiscal RR, Chavez AC. Development and physicochemical evaluation of wine from Taro corms (Colocasia esculenta) International Journal of Science and Research (IJSR) ISSN: 2319-7064. 2013. https://doi.org/10.21275/ART20161422

20. Balogu TV, Towobola O. Production and quality analysis of wine from honey and coconut milk blend using Saccharomyces cerevisiae. MDPI Basel, Switzerland. 2017. https://doi.org/10.3390/fermentation3020016

21. Atiyeh H, Duvnjak Z. Production of fructose and ethanol from sugar beet molasses using Saccharomyces cerevisiae ATCC 36858. National Library of Medicine 8600 Rockville Pike Bethesda, MD 20894. 2019. https://doi.org/10.1021/bp010164z

\section{Additional information}

Peer review information: Plant Science Today thanks Sectional Editor and the other anonymous reviewers for their contribution to the peer review of this work.

Reprints and permissions information is available at

https://horizonepublishing.com/journals/index.php/PST/open_access_policy

Publisher's Note: Horizon e-Publishing Group remains neutral with regard to jurisdictional claims in published maps and institutional affiliations.

To cite this article: Baua M A I. Development and acceptability of mead wine with calamansi fruit flavor. Plant Science Today. 2021;8(3):451-455. https://doi.org/10.14719/pst.2021.8.3.1069

Plant Science Today, published by Horizon e-Publishing Group, is covered by Scopus, Web of Science, BIOSIS Previews, Clarivate Analytics, etc. See https://horizonepublishing.com/journals/index.php/PST/indexing_abstracting 